\title{
Analysis of Traffic Performance of NH79 Road, Rajasthan, India
}

\author{
Lasmar Garba $^{1}$, Dr. Esar Ahmad ${ }^{1}$, Dr. Tanveer Ahmed Kazi ${ }^{2}$ \\ ${ }^{1,2}$ Department of Civil Engineering, Mewar University, Chittorgarh, \\ Rajasthan. India
}

\begin{abstract}
This research focused on analyzing the traffic performance of NH79 road from Chittorgarh/Bhilwara Rajasthan India. The road is currently a 2 way-direction with 3 lane carriageways in both the direction, after closely observation the problems identified, were traffic congestion, delay, prone to accident which associated with high traffic volume and inappropriate parking facilities. The parameters considered in this research were Capacity, Density, Saturation Ratio. After analysis conducted from the data collected, it was revealed that, the road section has an average daily capacity of 12609 veh/day and average hourly traffic flow of 1261veh/hour with average speed of 54 K.P.H. the traffic density of the road is $112 \mathrm{vs} / \mathrm{m}$, therefore based on the parameters evaluated it is concluded that road belongs to level of service $E$, this is because all the parameter are within the range service class $E$ in compliances with the recommendation made in the (HCM, 2000), thus it is recommended that the NH79 section shall be facilitated with proper Planning due to the fact the road is still growing and changing, resulting in a more responsive and useful transportation process, also Management and Maintenance will immensely help for the road to sustain its life span without deterioration and provision of well-integrated Traffic control system especially in Gangrar town junction will reduce the level conduction, delay prone to accident and travel time of the drivers and other road user.
\end{abstract}

Keywords: Performance, Traffic, Volume, Parameters, Delay

\section{0: INTRODUCTIONS}

A times, the expressway with multiple lane was considered to be the answer to making of the traffic problems associated with road high volume. When a multiple lane is used as the form of control at road high volume, its geometric features are of great impact on its ability to properly carry out its intended function. Apart from queuing delays which occur due to heavy traffic at peak hours, the geometric features of expressway with multiple lane could cause delays at other times throughout the day, thereby affecting traffic performance significantly. Congestion, particularly on city streets and urban freeways continue to pose a serious problem to traffic engineers. However, construction of new roads or widening of existing ones may not always be the solution for relieving congestion since the capacity of urban roads are generally governed by that of their intersection; the solution might be to increase the capacity of critical intersection rather than constructing new roads or widening the entire length of the road way.

According to research by (1) on The Effect Analysis of Traffic Volume, Velocity and Density in Dr. Siwabessy Salobar Road, they found the street is considered to be one of the busy streets in ambon city with various vehicles passing by along with the crowded pedestrian activities. Especially in the morning and evening hours, the flow analysis of Dr. siwabessy road traffic is said to have not experienced saturation because the ratio of volume to capacity has a value less than 1 . Based on their study it was found out that both traffic flow from ambon city to Air sabolar or vice versa shows the dominant influence of vehicles speed (Us) on traffic density(D) compared to traffic volume factor(V), (1) generated a regression model of DR. siwabessy road the formula for ambon to air salobar is $\mathrm{D}=18.32-0.35 \mathrm{U}_{\mathrm{s}}+0.024 \mathrm{Q}$ And that of air salobar to ambon is $\mathrm{D}=18.67-0.396 \mathrm{U}_{\mathrm{s}}+0.021 \mathrm{Q}$ where both have a very high correlation value of $\left(R_{2}=0.999\right)$. (2) found that the effective of management urban planning comes directly from the accurate data collections and analysis at various central business district (CBD), from the analysis of tanketipper intersection, they found that the existing capacity intersection is given as $4969 \mathrm{Vph}$ and practical capacity are $\mathrm{Q}_{\mathrm{p}}=4224 \mathrm{Vph}$ and $6676 \mathrm{Vph}$ as the new propose practical capacity. Also (2), research found that the video-graphy cost $\mathrm{N} 8,700$ while the manual counting method cost $\mathrm{N}$ 11,400 , they further concluded that the tanke-tipper intersection operate level of service $F$ which need a serious modification.

The operational performance of mengxi square rotary intersection in Zhenjiang, china was surveyed and analysed by (3) based on the following parameters which include vehicle velocity distribution, gap distribution and lane distribution which provide the basis for design and improving traffic flow on the rotary intersection, (3) concluded that the average velocity increase from lane 1 , lane 2 to lane 3 also the average velocity for Light vehicles is much compared to that of Heavy vehicles for all the sections. According to Assessment study conducted by (4) at Baban Gwari roundabout a rotary intersection along katsina road in Kano metropolis of Kano state of Nigeria. it was observed that the roundabout experienced daily and frequent concurrent delay, accidents, queue built up at morning and evening peak hours.

\section{0: NEED FOR THE RESEARCH}

NH79 Road Chittorgarh/Bhilwara section is presently a 2way with 3-lane carriageway in each direction in which traffic movement is very high mostly along gangrar because of a market presence. After closely observing the roads, the problems identified are high traffic volume which lead to traffic congestion because of crossing, inadequate parking facilities along gangrar market. Therefore, this study is necessary to explore the effects of the geometric features and traffic flow parameters as it 
affects the traffic performance of NH79 Road, Chittorgarh/Bhilwara's section.

\section{0: AIM AND OBJECTIVES OF THE STUDY}

\section{1: Aim}

The aim of the research work is to analyse the traffic performance of NH79 road, Chittorgarh/Bhilwara's section.

\section{2: Objectives of the Study}

The objectives of this study were

To conduct a preliminary survey on the existing features of Chittorgarh/Bhilwara's section of the NH79 road

To Determine traffic volume of Chittorgarh/Bhilwara's section of the NH79 road.

To Determine Operational Performance most specifically on Chittorgarh/Bhilwara's section of the NH79 road.

\section{0: GENERAL DESCRIPTION OF THE STUDY AREA} The NH79 is the road which links Chittorgarh and Bhilwara district within Rajasthan (India). it's also made up of rigid pavement having 2-way with 3-lane carriageway in each direction, each carriage way is $4.2 \mathrm{~m}$ and service lane which its currently under construction. other physical features of NH79 include

$>$ Roadway median: The roadway median in the NH79 has the height of $0.23 \mathrm{~m}$ and width of $5 \mathrm{~m}$.

$>$ Drainage: Drainage is one of the most important features in any road because it drains water from the road and discharge it to the discharging point, the drainage system along $\mathrm{NH} 79$ has the height of $0.6 \mathrm{~m}$ and width of $1.43 \mathrm{~m}$

$>$ Pedestrian walkway: The pedestrian walkways was constructed to in compliances with the IRC Provision it has width of $2 \mathrm{~m}$ and length of 0.25

$>$ Flyovers: There are currently 5 flyovers between gangrar to Chittorgarh four out of the five are fully constructed while one is under construction.

$>$ Service lane: The service lane in NH79 is currently under construction about $1.5 \mathrm{~km}$ is completed the service lane width is $7 \mathrm{~m}$

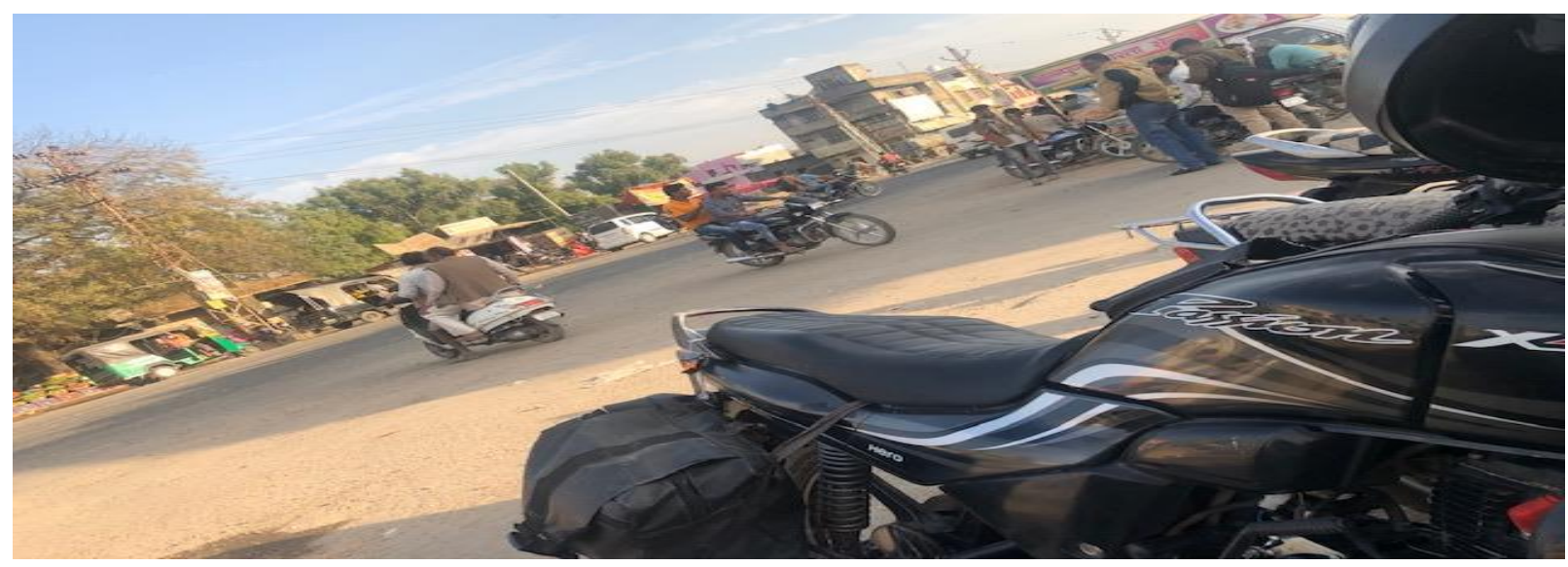

Figure 5.0: Portion of NH79 Road, Chittorgarh/Bhilwara's Section.

\section{0: METHODOLOGY}

The methods employed to obtained the required data for this research includes; Preliminary survey on the existing features of the NH79 road section, Traffic Volume study on section of NH79 road. Which was determined manually by using the Procedures Observers were positioned at various cross section of the roadway, the number of vehicles that passes each observer was noted The vehicles timing was expressed in hourly periods and different type of vehicle was categories and record for ten hours, This was repeated for a week. The results were tabulated and from the methods employed the relevant parameters such as passenger's car unit, Capacity, Density, Saturation Ratio were determined in order to assess the performance capacity of the road section used for the research. Also, average travel speed. Was determined by Procedures followed; The chosen distance was measured, the observer was stationed at initial point of measured distance, the specimen vehicle was identified, the time taken to reached the end point was noted, Then, the speed was calculated.

\section{0: ANALYSIS AND DISCUSSIONS OF RESULT 6.1: Traffic Volume Count Result}

Seven consecutive days traffic volume count was conducted for 10 hours count (08:00am-06:00pm) at the NH79 Chittorgarh/Bhilwara Road Rajasthan India. The traffic volume of the vehicle recoded during the survey was converted to passenger's car unit/equivalence using an appropriate conversion factors as stated in the Indian road congress (6). And the result was presented below. 


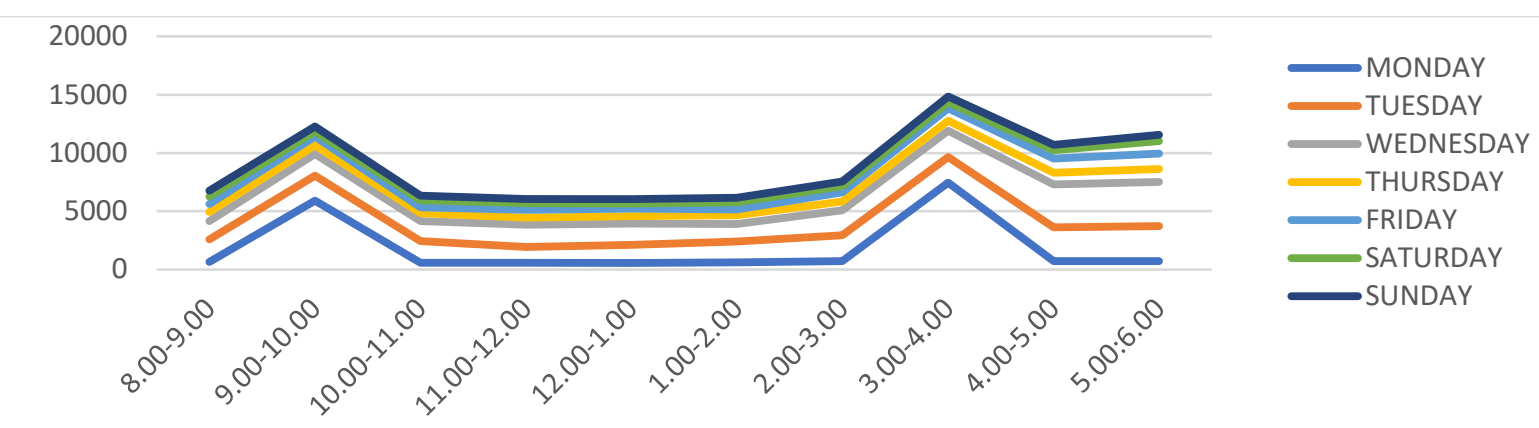

Figure 6.1.1: Traffic Volume Count of Chittorgarh/Bhilwara

The result of the Traffic Volume Count in Figure above revealed that there is increased of traffic in volume in the morning hours and with the 09:00am-10:00am as the morning peak hours and also having the 3:00pm-04:00pm as evening peak hours this shows that there is high volume of traffic in both morning and evening hours and less traffic during the mid-day hours, the average daily traffic obtained is $12609 \mathrm{veh} /$ day shows that the road is moderately dense in comparison with the recommendation of daily traffic volume stated Highway capacity manual (HCM 2000), therefore the road capacity can be seen as adequate.

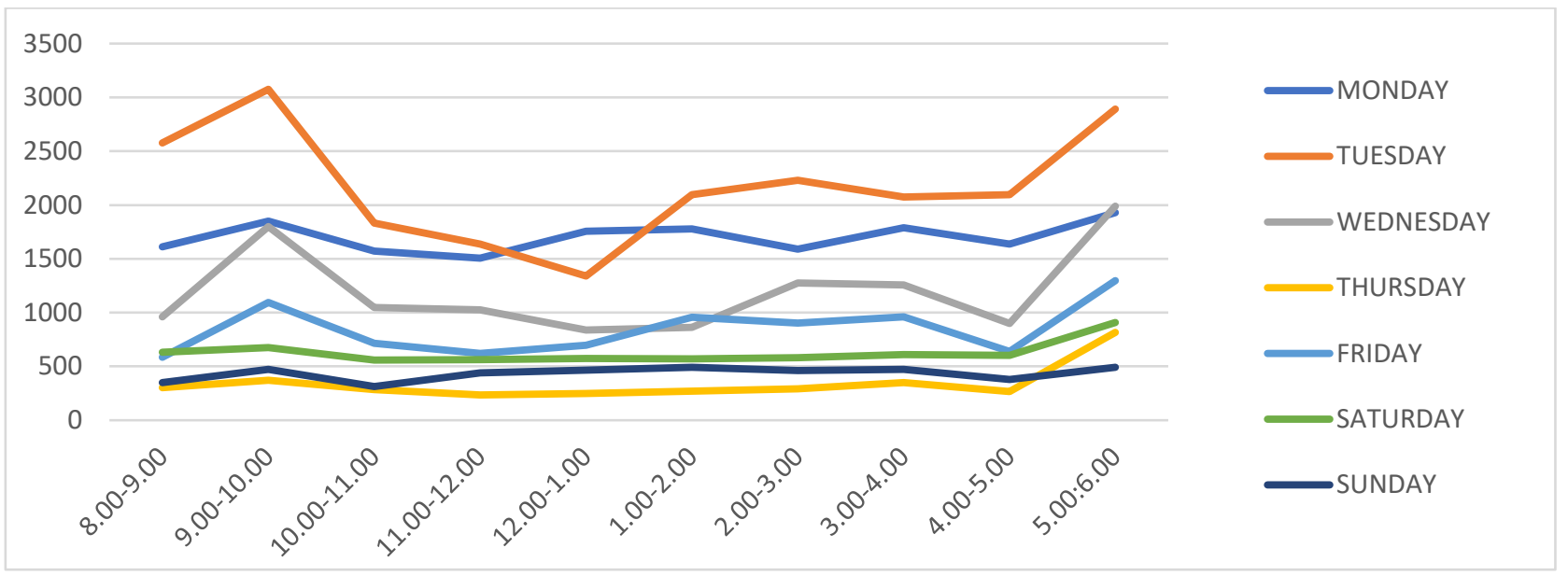

Figure 6.2: Passenger's Car Unit of Bhilwara/Chittorgarh

the result of the Traffic Volume Count of BhilwaraChittorgarh presented above follsow similar trend with its counter direction having morning peak hour period of 09:00am-10:00am and 05:00-06:00pm as evening hours' peak hour period, the average daily traffic obtained is
10477 veh/day shows that the road is highly dense in comparison of the recommendation of daily traffic volume stated Highway capacity manual (HCM 2000), therefore the road capacity can be seen as adequate.

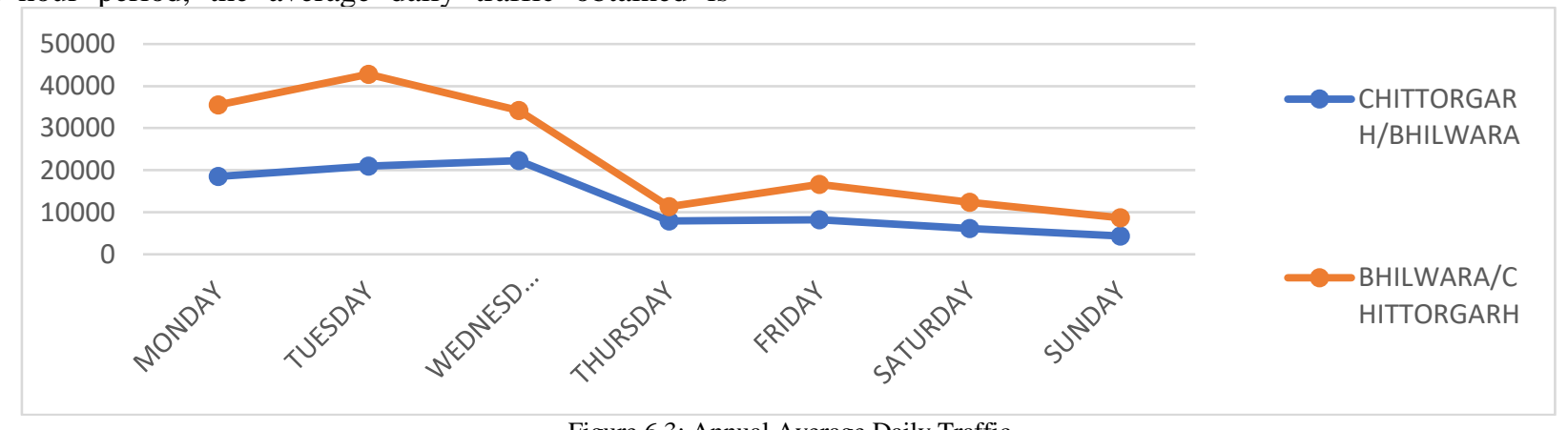

Figure 6.3: Annual Average Daily Traffic

The summary of annual average daily traffic obtained during the analysis can be seen that Bhilwara-Chittorgarh has little higher value compared with the Chittorgarh to Bhilwara. And Tuesday with the highest value while Sunday having lowest value. This may be due to higher population of people moving from the Chittorgarh to Bhilwara.

\section{4: Traffic Density}

Traffic density was evaluated and presented in the table and figure below 


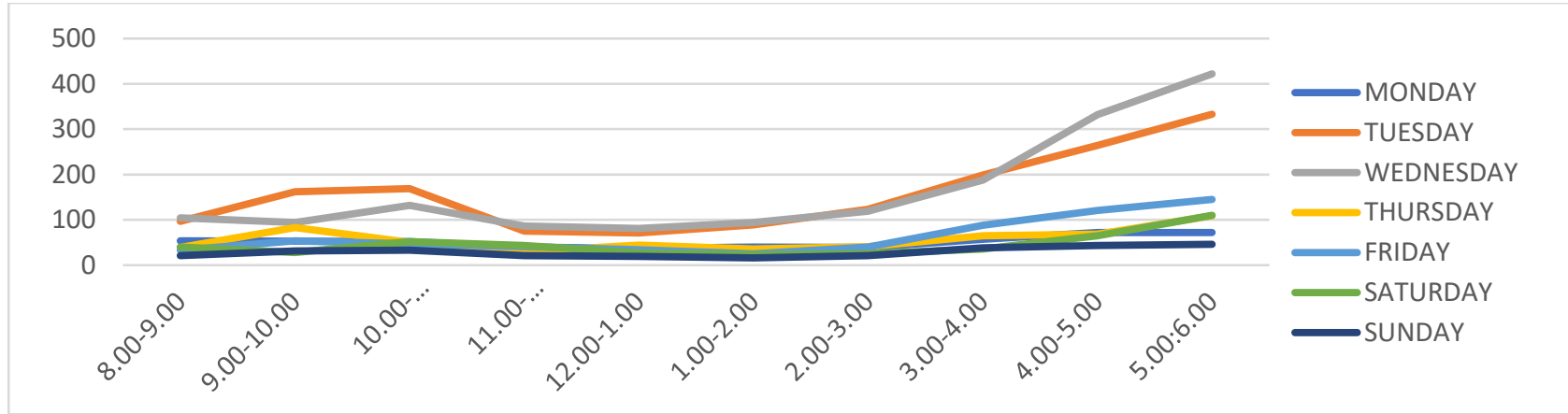

Figure 6.5: Traffic Density of Chittorgarh/Bhilwara

The result of the traffic presented above revealed that the road is highly dense in the morning hours between 08:0011:00am which correspond to morning peak hours' while at the evening hours there it increased from 03:00-06:00pm with Wednesday having the highest value while Sunday having the lowest value as shown in the figure above this happened due to variation of vehicles movement on the road. The daily density of this direction is $116 \mathrm{vs} / \mathrm{m}$ and it's within the range of the recommended value Highway capacity manual (HCM 2000),

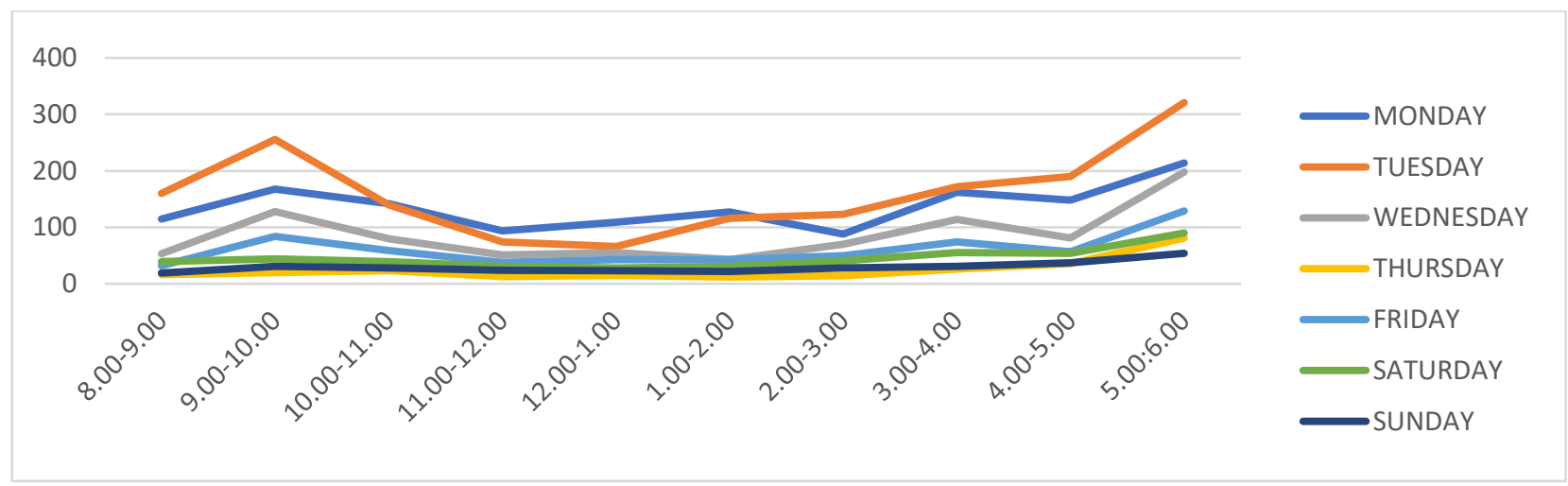

Figure 6.6: Traffic Density of Bhilwara/Chittorgarh

The same nature of traffic movement obtained along the Bhilwara/Chittorgarh when compared with the other direction but the peak hours here is 9-10am while the densely hours occurred between 04:00-06:00pm during midday hours there is less movement of traffic along the direction of the Bhilwara/Chittorgarh and the average daily density is $112 \mathrm{vs} / \mathrm{m}$ and when its compared with the Highway capacity manual (HCM 2000),

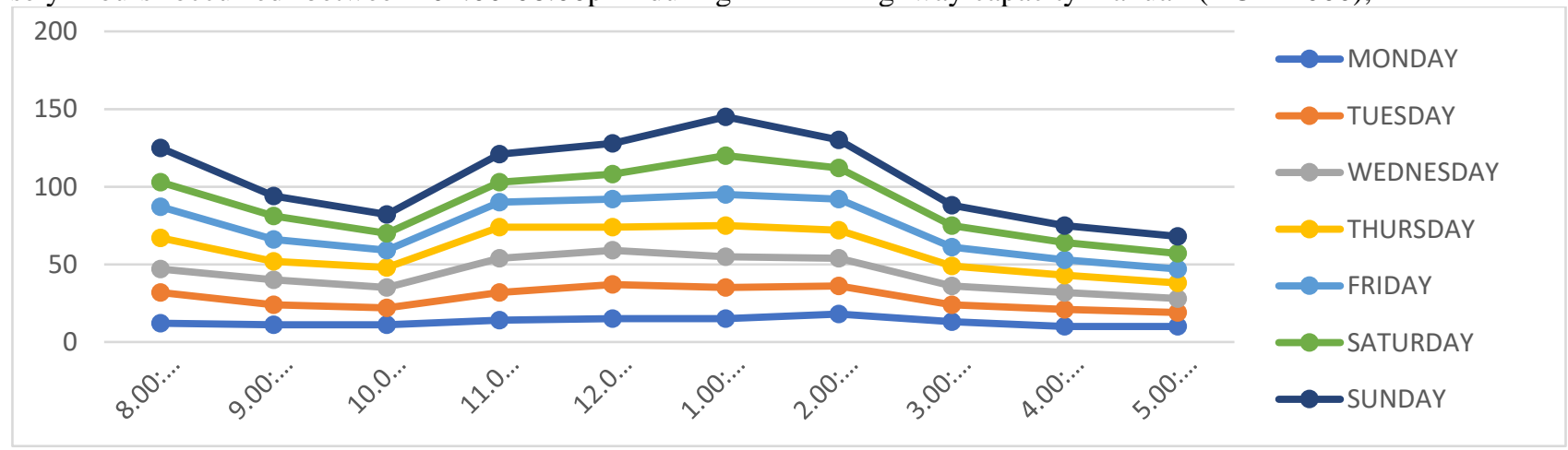

Figure 6.7: Average Hourly Speed Chittorgarh/Bhilwara

The result of vehicles speed were presented above revealed that there is less speed during both morning and evening peak hours, which resulted from the high flow traffic during morning and evening hours respectively, while the speed increases as the traffic flow decreases during midday $(12: 00 \mathrm{pm}$ to $03: 00 \mathrm{pm})$ this resulted from less movement of both commercial and private vehicle along the road. 


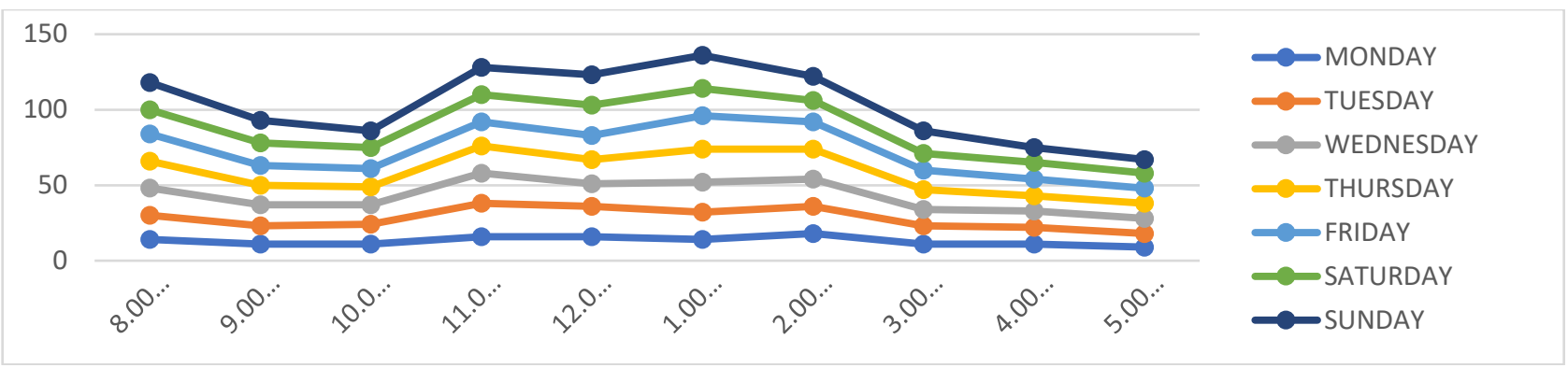

Figure 6.8: Average Hourly Speed Bhilwara/Chittorgarh

\title{
7.0: THE SPEED
}

The speed of the Bhilwara/Chittorgarh flow similar trend with that of Chittorgarh/Bhilwara the little difference is the average speed.

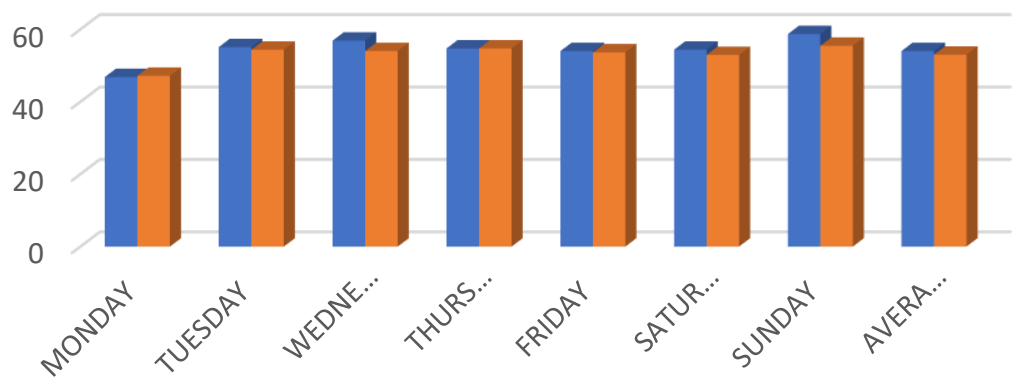

\author{
- CHITTORGARH/ BILWARA \\ SPEED $(\mathrm{kmp} / \mathrm{h})$ \\ BILWARA/ CHITTORGARH \\ SPEED $(\mathrm{kmp} / \mathrm{h})$
}

Figure 7.1: Average Speed of Moving Vehicles

The daily average speed of the vehicle which ranges from 46.8 to 54 K.P.H to conclude on the speed it can be categories as the level service E, It can be also be seen that the average speed of the vehicle is within the recommended speed of 50-60KPH Highway capacity manual (HCM 2000).

\section{2: Saturation Ratio}

The saturation level is very negligible having an average value of 0.1 for each hour this can be has little impact on the level of service of the road.

\section{0: GENERAL DISCUSSION}

The analysis preliminary conducted along the NH79 revealed that the road has high probability of accident this is because there is no any provision of traffic regulation the will guide vehicle and other road users such as pedestrian to the right path, also poor parking facilities is found to negate the smooth movement of vehicle due to rampant and irregular parking along the road side of the NH79 especially in gangrar junction market, this market proximity cause congestion, delay, and sometimes prone to accident potentialities along the road. the analysis of data of traffic volume count, traffic density, capacity, speed, level of saturation along the NH79 section revealed that the road has an average daily capacity 12609veh/day and average hourly traffic flow of $1261 \mathrm{veh} / \mathrm{hour}$ with average speed of 54 K.P.H, the traffic density of the road is 112 , therefore base on the parameters evaluated it can concluded that road can be level of service $\mathrm{E}$ this is because all the parameter are within the range with in compliances with the recommendation made in the (HCM, 2000).

\section{1: CONCLUSIONS}

With the result discussed above, the following conclusions were drawn.
The preliminary survey conducted on the NH79 road section revealed that it's made up of rigid pavement having 2-way with 3-lane carriageway in each direction, each carriage way is $4.2 \mathrm{~m}$ and service lane which its currently under construction there is no any provision of parking facilities along the road especially in Rangarar town where there is tendency of high volume of daily traffic due to the presence of market and railway station.

Traffic volume study carried out along the road section revealed that the peak hour volume occurs Chittorgarh/Bhilwara in the morning (09:00am-10:00am) and evening (3:00pm-04:00pm) hours with average daily volume of $12609 \mathrm{veh} /$ day while Bhilwara/Chittorgarh direction has morning peak hour period between 09:00am to 10:00am and 05:00 to $06: 00 \mathrm{pm}$ as evening hours' peak hour period with an average traffic obtained is $10477 \mathrm{veh} /$ day respectively and less flow of traffic is experience during midday hours due to less movement of vehicles during the period which former conditions associated with less speed of and later conditions with an incremental speed of 53.5K.P.H. all falls within the recommended range of speed limit of 50-60K.P.H Highway capacity manual (HCM 2000).

Operational Performance or level of service of NH79 road section can be categories as $\mathrm{E}$ this is because the average speed is 53.5K.P.H the average daily traffic volume of $11543 \mathrm{Veh} /$ day an average traffic density of 114 as well as the saturation capacity of 0.1 therefore the road is within its good condition of operation using Highway capacity manual (HCM 2000). 


\section{0: FUTURE SCOPE/RECOMMENDATIONS}

Based on survey and analysis of result, the following recommendations can be drawn from the study.

Planning: Although the NH79 road is still growing and changing, and undoubtedly many of the methods and procedures used today will be modified in the future, resulting in a more responsive and useful transportation process such as provision of parking facilities along in Rangarar, town.

Management and Maintenance: traffic management system is also important as the design of the road facilities itself, unless the system is adequately managed so to serve its function well. Therefore, there is need for the continuous maintenance to prolong the service life of the road.

Traffic control system: regulation of traffic by provision traffic signal system along the NH79 especially in Rangarar town junction will reduce the level conduction, delay prone to accident and travel time of the drivers and other road user.

\section{0: REFERENCE}

[1] Selviana walsen, La mohamat (2017) "The effect analysis of traffic volume, velocity and density in Dr. siwabessy salobar road. International journal of advanced Engineering Research and Science. Vol-4 issue 11, Nov. ISSN: 2349-6495

[2] Jimoh Y.A, Itiola I. O. and Adeleke O.O. (2014) Traffic Performance Analysis and Cost Comparison of Data Collection Methods for an Urban Rotary. International journal of traffic and transportation Engineering(2014).

[3] Ying Liu et,al (2013) "Analysis of traffic operation performance at roundabouts. In

[4] Govind Singh Chauhan, Auwal Alhassan Musa and Lasmar Garba (2020) "performance assessments of rotary intersection capacity (case study of baban gwari round about)" Compliance Engineering Journal Volume 11, Issue 2, 2020 Pp:207- 213

[5] Highway capacity manual, HCM-2000. Transportation Research Board, Washington DC, 2000.

[6] Guidelines For Capacity Of Urban Roads In Plain Areas IRC: 106-1990 